\title{
An Introductory Study on Activated Carbon Monolith Electrodes Fabrication from Teak Leaf Waste
}

\author{
Erman Taer', Miftah 'Ainul Mardiah', Sugianto ${ }^{3}$, Rita Juliani', Awitdrus ${ }^{5}$ \\ and Rakhmawati Farma ${ }^{6}$
}

1,2.3,4,5,6 Department of Physics, Faculty of Mathematics and Natural Science, Universitas Riau, Pekanbaru 28293, Riau, Indonesia

\begin{abstract}
A preliminary study has been conducted on supercapacitor carbon-electrode monolith prepared from teak leaf waste. The objective of this study is to know the electrochemical cell capacitance from carbon materials. The production of carbon electrode began with pre-carbonization process at $250^{\circ} \mathrm{C}$ for 2.5 hours, then proceeded to chemical activation using $\mathrm{KOH}$ activator with concentration of $0.3 \mathrm{M}$. Hydraulic Press was used with pressure at 8 ton to form the monolith. Then, the density was measured the carbonization. After that the sample was activated using $\mathrm{CO}_{2}$ gas at $850^{\circ} \mathrm{C}$ burning temperature. Next after the carbonization, the density was measured by collecting mass, diameter and thickness data of the electrode. The specific capacitance was measured using Physics CV UR Rad-ER 5481 which is controlled by a cyclic voltammetry software with the potential window width of $0-0.5 \mathrm{~V}$ and at a scan rate of $1 \mathrm{mV} / \mathrm{s}$. The best density results obtained were 0.853 $\mathrm{g} / \mathrm{cm}^{3}$ before carbonization for sample code $\mathrm{C} 24$ and $0.605 \mathrm{~g} / \mathrm{cm}^{3}$ after carbonization for sample C30. The specific capacitance was found at $113.20 \mathrm{G} / \mathrm{g}$ for C32 and C38 electrodes
\end{abstract}

Keyword:Teak leaf waste, activated carbon, supercapacitor

Received 10 December 2018 | Revised [10 January 2019] | Accepted [28 February 2019]

\section{Introduction}

Electrical energy has become world's primary needs and brought big impacts to all lives aspects. The energy needs in Indonesia is still dependent on fossil fuel like crude oil, coal and natural gas as sources for electrical energy. This has impacted on air pollution and will affect the people's lives and health [1]. Besides that, crude oil is non-renewable energy as it takes longer time to produce than the exploitation.

Energy storage devices become one of the solutions as alternative energy, for example devices like batteries, fuel cells and capacitor. Batteries and fuel cells are capable to store high energy but with very little power, while capacitor has big power but is only capable to store small energy. Another device, as an advancement to capacitor, usually known as supercapacitor is made to allow a device with not only big power but also large energy storage [2-5].

\footnotetext{
*Corresponding author at: Bina Widya Km 12.5 Simpang Baru Pekanbaru, 28293, Riau, Indonesia.

E-mail address: miftahainul.mardiah@gmail.com
} 
Supercapacitor consists of electrodes, separator, electrolytes and current collector. The Electrodes in supercapacitors have big effect on the energy and power capability of the supercapacitors. A popular material for supercapacitor electrodes is activated carbon with nanometer pores. Activated carbon from biomass can be made of bagasse, coconut shells and fibers, rice husk, sawdust, hard wood, coal also waste leaf.

Teak leaf are one of biomass waste that is interesting to be studied about as raw material for activated carbon because it is the biggest part of a Teak tree. It is considered as a deciduous tree that shed leaves at dry season, between November and January. After that, the leaves grow again in January or March. Fell off Teak leaves are suitable as biomass in supercapacitor fabrication as it reduces the amount of leaf waste produced. The carbon (C) content in Teak leaves is high, around $46.49-52.32 \%$ [6].

\section{Materials and Methods}

Electrodes fabrication started by collecting Teak leaf waste as the raw material. The sample was dried in an over at $110^{\circ} \mathrm{C}$ for 2 days. Then, pre-carbonization was done at $250^{\circ} \mathrm{C}$ for 2.5 hours in order to get brittle sample to ease the milling process in ball milling for 20 hours. In order to get fine and uniformity of pre-carbonized sample, the sieve with a size of $53 \mu \mathrm{m}$ was used to get particles smaller than $53 \mu \mathrm{m}$. Chemical activation process was done by $\mathrm{KOH}$ activation of 0.3 $\mathrm{M}$ to increase the surface area. Then, the sample was neutralized and dried in an oven at $110^{\circ} \mathrm{C}$ for 3 days until dry. Dried sample was refined and weighed $0.7 \mathrm{~g}$ for 10 samples and they were molded into pellets. The molding process was done using hydraulic press at 8 tons pressure and given code $\mathrm{C} 32$ to $\mathrm{C} 38$. The carbonization process was done in a furnace at $600^{\circ} \mathrm{C}$ in $\mathrm{N}_{2}$ environment and followed by physical activation at $850^{\circ} \mathrm{C}$ in $\mathrm{CO}_{2}$ gas environment. After that, the sample was polished carefully with sandpapers (Hammer P1200) to reach certain thickness.

The measurement done to sample was electrode dimension like mass, diameter, thickness and specific capacitance. The mass was measured using digital scales while the diameters and thickness were measured using Insize digital calipers. Those measurements were done after pellets molding and carbonization to observe the difference in density of the electrodes. The density was determined with the standard formula by dividing the mass and volume. Supercapacitor cell specific capacitance was done by Cyclic Voltammetry (CV) method using Physics CV UR Rad-Er 5841 controlled by cyclic voltammetry CVv6 software with the potential window width of $0-0.5 \mathrm{~V}$ at $1 \mathrm{~m} \mathrm{~V} / \mathrm{s}$ scan rate. The results obtained were processed by sigma plot 8.0 program. Specific capacitance cell was done in sulfuric acid $\mathrm{H}_{2} \mathrm{SO}_{4} 1 \mathrm{M}$ electrolyte. 


\section{Result and Discussion}

\subsection{Mass, thickness, diameter and density}

The mass of supercapacitor electrode cells before and after carbonization-activation process is shown in Figure 1. Based on the mass comparison diagram, sample mass before carbonization is different. The differences are caused by different condition during the molding process. Initial sample mass should be made the same as initial sample was weighed with the desired weight such as $0.7 \mathrm{~g}$. The difference occur due to the non-uniformity in the mass before the molding process. However, the error due to mass factor is predicted to be relatively small at $5 \%$. After the carbonization-activation, sample would shrink. The reduction in mass is caused by the released of non-carbon material like water, then the decomposition of organic compounds that make up the raw material like hemicellulose, cellulose and lignin [7]. The comparison of mass shrinkage after carbonization - activation is at $71.1 \%$ to $73.3 \%$. The variations of sample shrinkage indicated differences in sample arrangement in the burning tube.

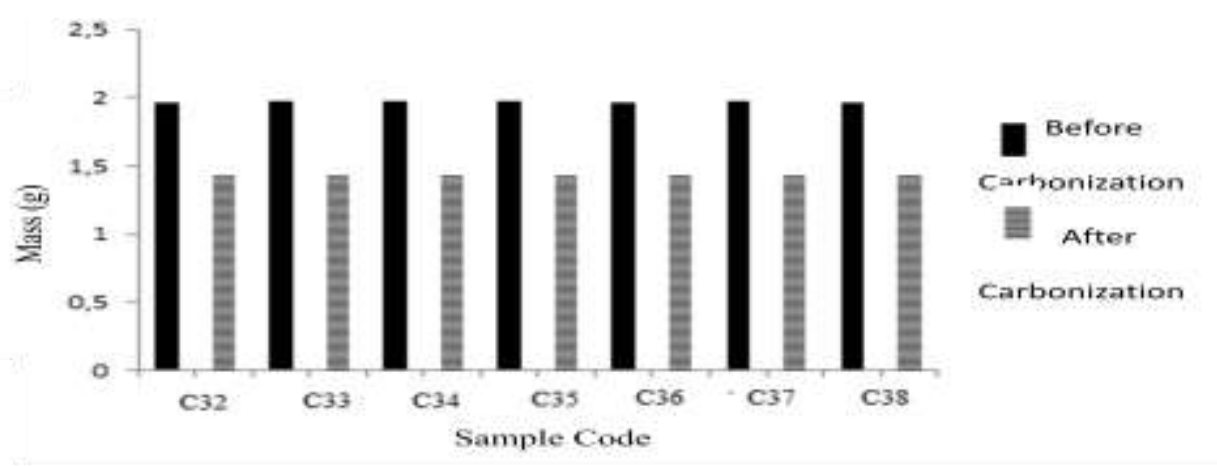

Figure 1. Mass Diagram for Before and After Carbonization

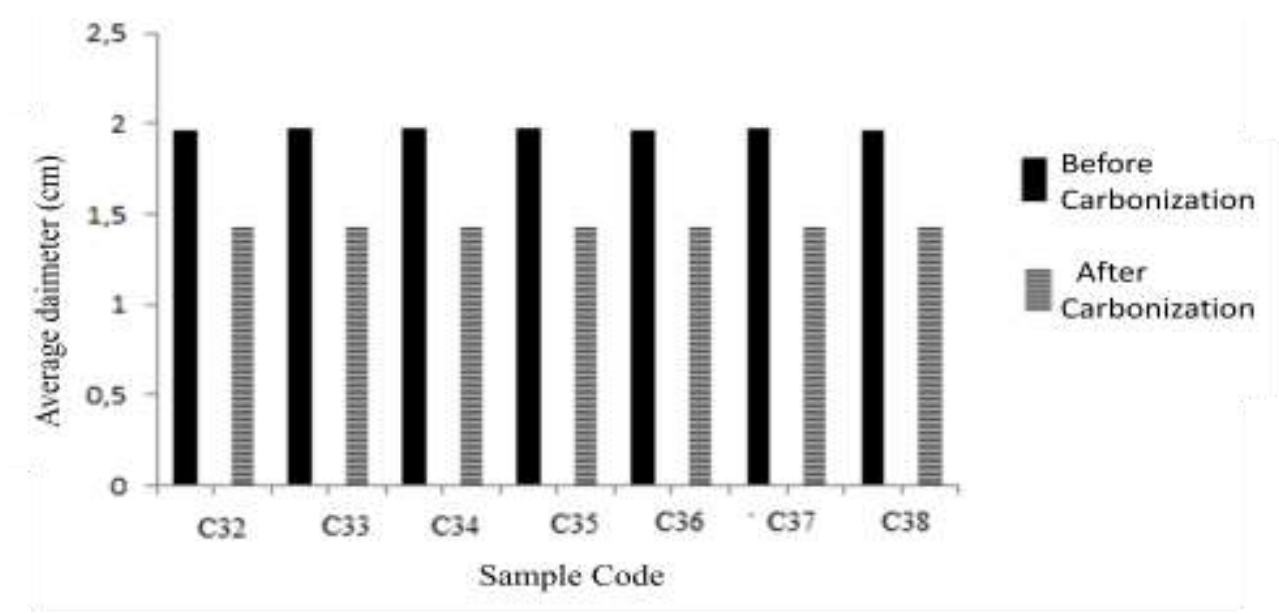

Figure 2. Average Diameter Diagram Before and After Carbonization 
Figure 2 shows sample diameters before and after carbonization - activation process. The data shows that the diameters are the same for all samples as all the molds have the same size which is $2 \mathrm{~cm}$. The same sample diameters after the process is due to the treatment given with the same temperature, gas flow rate and time activation. Diameter shrinkage given was $27 \%$.

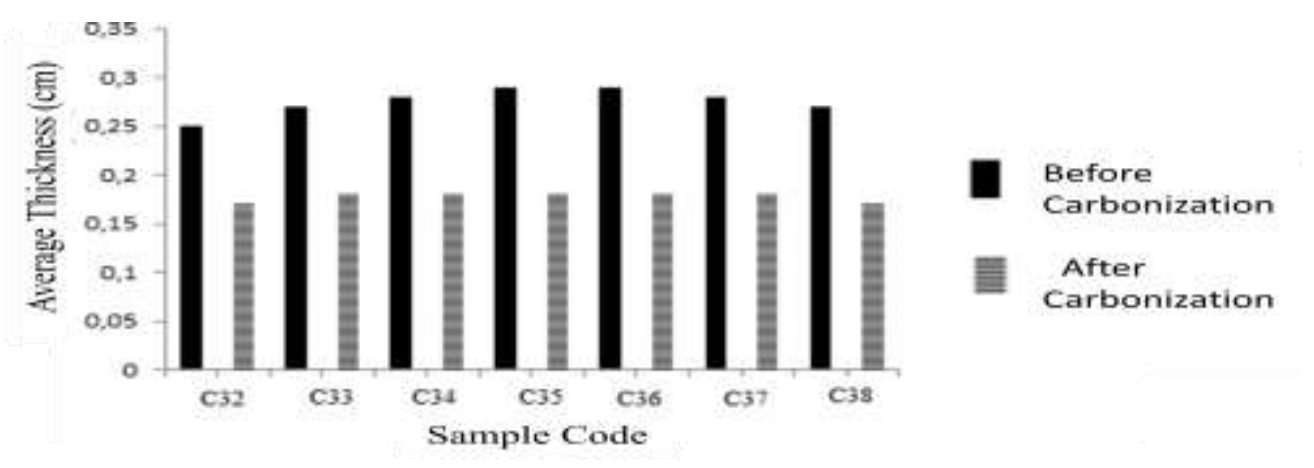

Figure 3. Average thickness diagram before and after carbonization

The thickness of sample before and after carbonization - activation is different due to the fact that it underwent shrinkage. It can be seen from Figure 3 that there are slight variances of sample initial thickness. This variances are influence by several factors such as different mass sample and pressure strength when sample was molded. The differences in the initial condition may cause the thickness difference after carbonization-activation process. There is a range of $32 \%-37 \%$ of thickness reduction after carbonization.

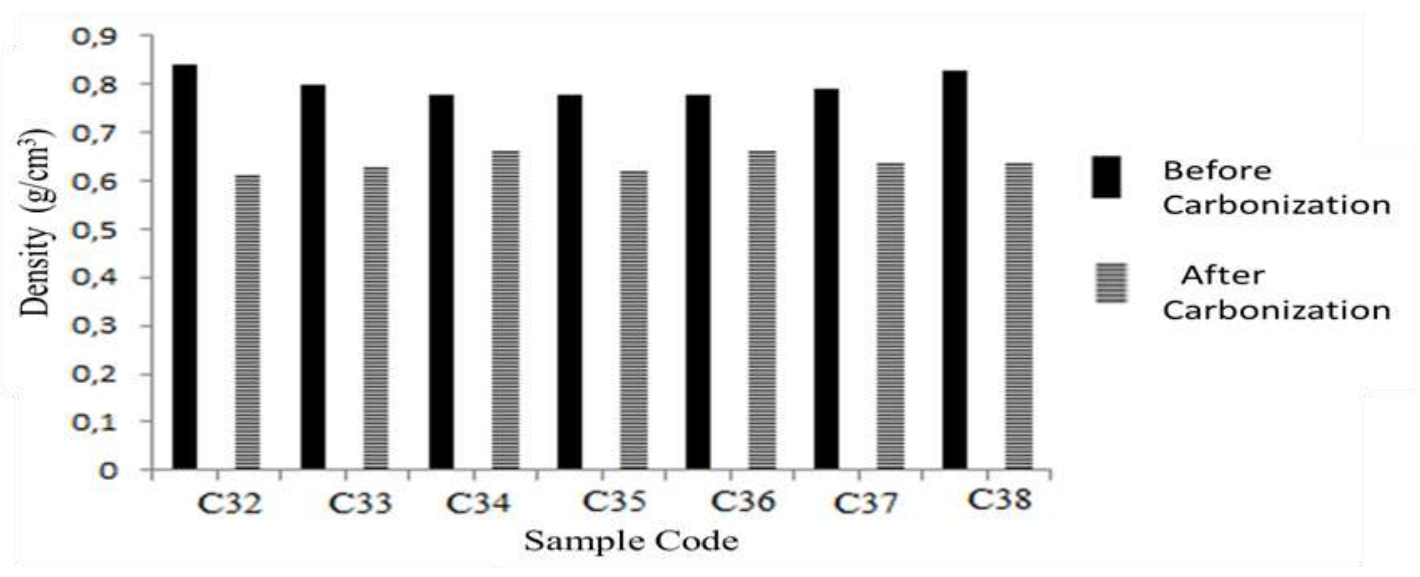

Figure 4. Density diagram before and after carbonization

There is a reduction in the density before and after carbonization - activation as shown in Figure 4. Irregular trend was obtained for the density of the 9 samples. The values for several samples were high before the process, for instance $0.84 \mathrm{~g} / \mathrm{cm}^{3}$ and $0.83 \mathrm{~g} / \mathrm{cm}^{3}$ for sample code C32 and C38 respectively. Meanwhile sample C38 and C37 gave low density values such as $0.78 \mathrm{~g} / \mathrm{cm}^{3}$ 
and $0.79 \mathrm{~g} / \mathrm{cm}^{3}$ respectively. The percentage difference of high and low density values before the process is $5.9 \%$.

Sample density after carbonization - activation process was high for several sample like C34 and $\mathrm{C} 38 ; 0.66 \mathrm{~g} / \mathrm{cm}^{3}$ and $0.64 \mathrm{~g} / \mathrm{cm}^{3}$ respectively, while low density values were given by sample $\mathrm{C} 35$ and $\mathrm{C} 32$ at $0.62 \mathrm{~g} / \mathrm{cm}^{3}$ and $0.61 \mathrm{~g} / \mathrm{cm}^{3}$. The percentage difference of high and low density values after the process is $4.6 \%$.

The varieties of density before and after carbonization - activation are in lower range which is within $10 \%$. This shows that the precision of electrode fabrication process is relatively good. The density shrinkage before and after the process is at $15 \%$ to $27 \%$.

Overall, the highest shrinkage rate for mass, diameter, thickness and density values are $73.3 \%$, $27 \% 37 \%$ and $27 \%$ respectively. The highest shrinkage given is by mass variable which is considered as reasonable because the reduction of mass has effects on both diameter and thickness reductions. A similar results on mass decrease is shown in a study done by Dewi [8] for durian peel waste, with $70 \%$ of shrinkage. Similarly, the research by Mustika [9] with oil palm empty bunches gave $73 \%$ differences.

The shrinkage for diameters, thickness and density values are at similar values. The same result was found in a study by Susanti [10] about banana stem in which the decrease rate was $27 \%$, $36 \%$ and 26\%. This is also shown in Afrianda [11] study to Sago pulp which gave shrinkage rate at $25 \%, 37 \%$ and $20 \%$.

\subsection{Electrochemical Properties Measurement}

The measurement of electrochemical properties using Cyclic Voltammetry (CV) with $1 \mathrm{mV} / \mathrm{s}$ scan rate aims to determine the supercapacitor cell's specific capacitance. An example of CV measurement to supercapacitor cell is shown in Figure 5 of sample carbon C34 and C33. The curve from $\mathrm{CV}$ shows the relationship between current density and given voltage. The current magnitude can be linked with produced specific capacitance of the electrodes. The wider and larger the curve is, the higher the electrodes cell specific capacitance is. The measurement of specific capacitance was carried out by taking the median values of potential window, which is 0.25V. In the Figure 5, data CV for C34 and C33 samples are shown.

The equation used for specific capacitance values calculation is:

$$
C_{s p}=\frac{\left(I_{c}-I_{d}\right)}{s \times m}
$$

where $I_{c}$ is the current charge, $I_{d}$ is the current discharge, $s$ is the scan rate and $m$ is average mass. $\mathrm{I}_{\mathrm{c}}$ produced was $0.001118 \mathrm{~mA}, \mathrm{I}_{\mathrm{d}}$ was $-0.001316 \mathrm{~mA}$, s was $1 \mathrm{mV} / \mathrm{s}$ and the mass was 0.0215 gram. Therefore the $C_{s p}$ value was $113.20 \mathrm{~F} / g$. $I_{c}$ and $I_{d}$ values produced from the 
equipment used to calculate $\mathrm{C}_{\mathrm{sp}}$, which is Physics CV UR Rad-Er 5841, is controlled by cyclic voltammetry CVv6 software.

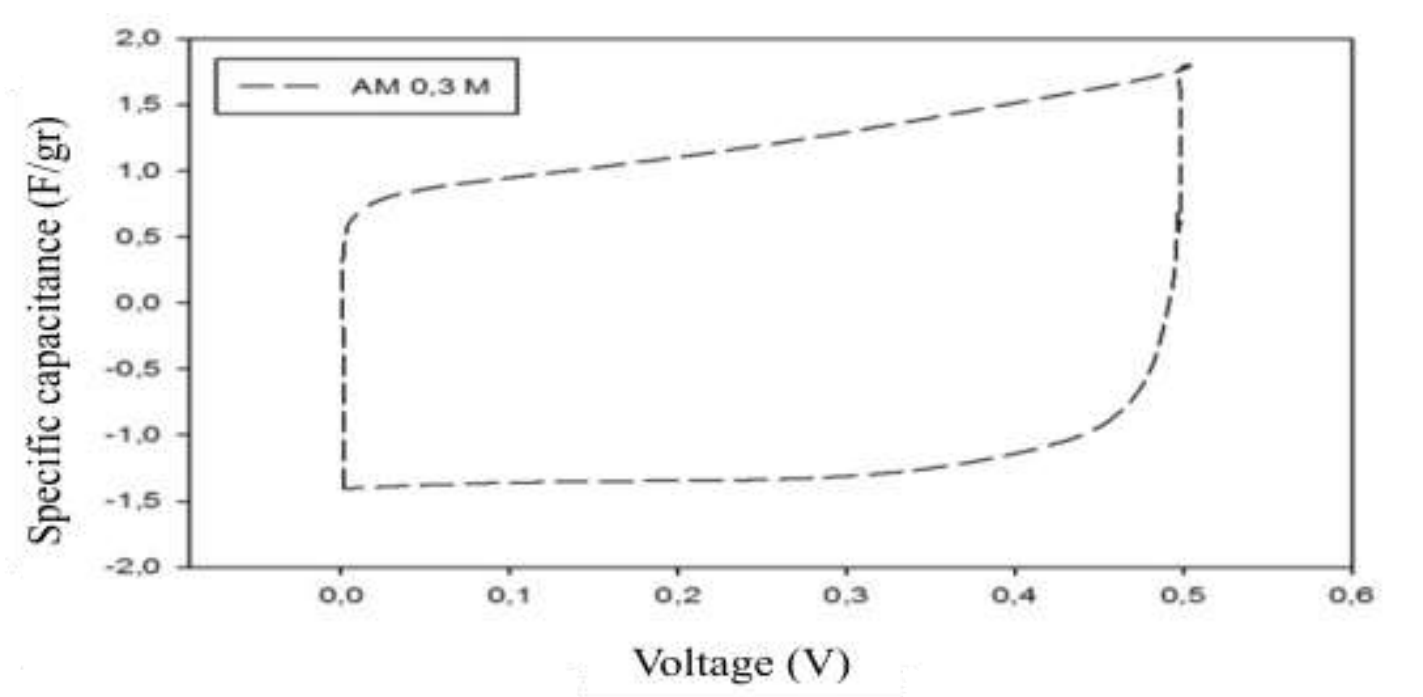

Figure 5. Relationship curve between specific capacitance and voltage at $1 \mathrm{mV} / \mathrm{s}$ scan rate The complete specific capacitance values of every electrodes used are shown in Table 1. The different values percentage of the supercapacitor cell's specific capacitance is $13 \%$. This difference is influenced by the change of electrodes' dimensions where sample C38 and C37 have got average of 72.55 change in the mass after the activation. A higher change in the dimension was caused by sample arrangement factors in carbonization-activation room. Sample $\mathrm{C} 37$ and $\mathrm{C} 38$ were arranged to be nearer at $\mathrm{N}_{2}$ and $\mathrm{CO}_{2}$ sources. These factors have caused sample C37 and C38 to have higher capacitance.

Table 1 Specific capacitance $\left(\mathrm{C}_{\mathrm{sp}}\right)$ of several pellets produced

\begin{tabular}{ccc}
\hline Cell & Sample Code & Capacitance value $\left(\mathrm{C}_{\mathrm{sp}}\right)$ \\
\hline 1 & C38, C37 & $112 \mathrm{~F} / \mathrm{g}$ \\
2 & C36, C35 & $105 \mathrm{~F} / \mathrm{g}$ \\
3 & C33, C32 & $97 \mathrm{~F} / \mathrm{g}$ \\
\hline
\end{tabular}

Specific capacitance of capacitor from Teak leaf waste electrodes was compared to several different sources that can be seen on Table 2. The data shown tells that the specific capacitance values of carbon electrode from Teak leaves to be at the acceptable range to be reported. This research shows that the usage of carbon from Teak leaf waste has got a good potential as the raw material for activated carbon electrode of supercapacitor cells.

Table 2 The comparison of specific capacitance values from activated carbon electrodes of different biomass

\begin{tabular}{ccc}
\hline Biomass & $\mathrm{C}_{\mathrm{sp}}$ & Reference \\
\hline Rice Husk & $147 \mathrm{~F} / \mathrm{g}$ & Taer et al [12] \\
Rubber Tree & $154.03 \mathrm{~F} / \mathrm{g}$ & Teo et al [13], Tang et al [14], Peng et al [15], \\
& & Liu et al [16] \\
Rice Husk & $19 \mathrm{~F} / \mathrm{g}$ & Kuratani et al [17] \\
Wood Sawdust & $34 \mathrm{~F} / \mathrm{g}$ & Taer et al [18], Yan et al [19], Farma et al [20] \\
Rubber & & The results of this study \\
Teak Leaf Waste & $113.30 \mathrm{~F} / \mathrm{g}$ &
\end{tabular}


Activated carbon electrodes from Teak leaf waste has been successfully produces as supercapacitor cell electrodes. Carbonation - activation process shows changes in mass, diameter, thickness and density of $73.3 \%, 27 \%, 37 \%$ and $27 \%$ respectively. The specific capacitance of the supercapacitor cell produced is $113.20 \mathrm{~F} / \mathrm{g}$. The result of this study has shown that Teak leaf waste has the potential to be developed as supercapacitor electrodes.

\section{Acknowledgement}

The author thanks DRPM Dikti through its Penelitian Dasar Unggulan Perguruan Tinggi Project (PDUPT) in 2018 with "Potensi Pemanfaatan Limbah Padat Perkotaan sebagai Elektroda Superkapasitor" theme.

\section{REFERENCES}

[1] J. S. Slamet and Chahaya, Kesehatan Lingkungan, Yogyakarta: Gadjah Mada University Press, 2004.

[2] S. Arepalli, H. Fireman, C. Huffman, P. Moloney, P. Nikolaev, L. Yowell, C. D. Higgins, K. Kim, P. A. Kohl and S. P. Turano, "Carbon-nanotube Based Electrochemical Doble Layer Capacitor Technologies for Space Flight Applications," J. Mater., vol. 57, pp. 26-31, 2005.

[3] Y.-S. Kim and et al, "Out-of-plane growth of CNTs on graphene for supercapacitor applications," Nanotechnology, vol. 23, no. 1, p. 015301, 2011.

[4] M. Meyyappan, "Nanostructured materials for supercapacitors," Journal of Vacuum Science \& Technology A: Vacuum, Surfaces, and Films, vol. 31, no. 5, p. 050803, 2013.

[5] Vangari, Manisha, T. Pryor and L. Jiang, "Supercapacitors: review of materials and fabrication methods," Journal of Energy Engineering, vol. 139, no. 2, pp. 72-79, 2012.

[6] Supriyono, Haryono, Prehaten and Daryono, "Kandungan Unsur Hara dalam Daun Jati yang Jatuh pada Tapak yang Berbeda," Jurnal Ilmu Kehutanan, vol. 8, p. 2, 2014.

[7] M. Faisal, I. Andynapratiwi and P. Putri, "Pengaruh Komposisi Arang dan Perekat Terhadap Kualitas Biobriket dan Kayu Karet," Jurnal Teknik Kimia, vol. 2, no. 20, pp. 3644, 2014.

[8] P. Dewi, Pengaruh Variasi Waktu Pengaktifan Menggunakan Uap Air dalam Pembuatan Elektroda Karbon dari Limbah Kulit Durian untuk Aplikasi Superkapasitor, Pekanbaru: Jurusan Fisika, FMIPA Universitas Riau, 2017.

[9] W. S. Mustika, Pemanfaatan Potensi Tandan Kosong Kelapa Sawit Sebagai Karbon Aktif untuk Pembersih Air Limbah Aktivitas Penambangan Emas di Teluk Kuantan, Pekanbaru: Jurusan Fisika, FMIPA Universitas RIau, 2016.

[10] Y. Susanti, Pengaruh Variasi Suhu Aktivasi CO2 Terhadap Pembuatan Karbon Aktif Monolith dari Batang Pisang untuk Elektroda Superkapasitor, Pekanbaru: Jurusan Fisika, FMIPA Universitas Riau, 2017.

[11] A. Afrianda, Pembuatan dan Karakterisasi Elektroda Karbon Sel Superkapasitor dari Bahan Ampas Sagu Menggunakan Aktivasi H2O Berdasarkan Variasi Waktu Aktivasi, Pekanbaru: Jurusan Fisika, FMIPA Universitas Riau, 2018.

[12] E. Taer, Desmawati, Sugianto and R. Taslim, "Pembuatan dan Karakterisasi Sifat Fisika Green Carbon Paper Tanpa Menggunakan Perekat Menggunakan Biomassa," in Prosiding Seminar Nasional Fisika, 2015.

[13] E. Y. L. Teo, L. Muniandyb, E. Ngb, F. Adamb , F. Mohsmedc and R. Josea, "High Surface Area Activated Carbon from RIce Husk as a High Performance Supercapacitor 
Electrode," ELectrochimica Acta, vol. 192, pp. 110-119, 2016.

[14] W. Tang and et al, "Natural biomass-derived carbons for electrochemical energy storage," Materials Research Bulletin, vol. 88, pp. 234-241, 2017.

[15] L. Peng and et al, "Super-hierarchical porous carbons derived from mixed biomass wastes by a stepwise removal strategy for high-performance supercapacitors," Journal of Power Sources, vol. 377, pp. 151-160, 2018.

[16] T. Liu and et al, "Revitalizing carbon supercapacitor electrodes with hierarchical porous structures," Journal of Materials Chemistry A, vol. 5, no. 34, pp. 17705-17733, 2017.

[17] K. Kuratani, K. Okuno, T. Iwaki, M. Kato, N. Takeichi, T. Miyuki, T. Awazu, M. Majima and T. Sakai, "Converting Rice Husk Activated Carbon into Active Material for Capacitor Using Three Dimensional Porous Current Collector," Journal of Power Sources, vol. 196, pp. 10788-10790, 2011.

[18] E. Taer, M. Deraman, I. A. Talib, A. A. Umar, M. Oyama and R. M. Yunus, "Physical, Electrochemical and Supercapacitive Properties of Activated Carbon Pellets from Precarbonized Rubber Wood Sawdust by CO2 Activation," Current Applied Physics, vol. 10, pp. 1071-1075, 2010.

[19] J. Yan and et al, "Recent advances in design and fabrication of electrochemical supercapacitors with high energy densities," Advanced Energy Materials, vol. 4, no. 4, p. 1300816, 2014.

[20] R. Farma and et al, "Preparation of highly porous binderless activated carbon electrodes from fibres of oil palm empty fruit bunches for application in supercapacitors," Bioresource technology, vol. 132, pp. 254-261. 